This is an electronic reprint of the original article. This reprint may differ from the original in pagination and typographic detail.

Author(s): Tuomi, Margaret; Lehtomäki, Elina; Matonya, Magreth

Title: $\quad$ As Capable as Other Students: Tanzanian Women with Disabilities in Higher Education

Year: $\quad 2015$

Version:

Please cite the original version:

Tuomi, M., Lehtomäki, E., \& Matonya, M. (2015). As Capable as Other Students: Tanzanian Women with Disabilities in Higher Education. International Journal of Disability, Development and Education, 62(2), 202-214.

https://doi.org/10.1080/1034912X.2014.998178

All material supplied via JYX is protected by copyright and other intellectual property rights, and duplication or sale of all or part of any of the repository collections is not permitted, except that material may be duplicated by you for your research use or educational purposes in electronic or print form. You must obtain permission for any other use. Electronic or print copies may not be offered, whether for sale or otherwise to anyone who is not an authorised user. 


\title{
As Capable as Other Students: Tanzanian women with disabilities in higher education
}

\author{
Margaret Tuomia*, Elina Lehtomäkib, and Magreth Matonyac \\ aFinnish Institute for Educational Research, University of Jyväskylä, Finland; \\ ${ }^{b}$ Faculty of Education, University of Jyväskylä, Finland; 'School of Education, \\ University of Dar es Salaam, Tanzania
}

Globally, persons with disabilities are underrepresented in higher education. In Sub-Saharan Africa, where opportunities for higher education are especially limited, women are unlikely to continue their education. This research investigates women in Tanzanian higher education with the double marginalisation of being a woman and having disabilities. The women were interviewed on what factors enabled access and participation for their educational success. A thematic analysis of qualitative data was applied. All the women interviewed were motivated to complete their degrees. Key enabling factors were encouragement from their families and previous teachers, full participation in student life and sufficient financial support. Student life integration, especially peer study groups, and university staff training were emphasised along with structural modifications needed for campus facility access. They understood the importance of education, especially as women with disabilities, and the impact educated women with disabilities have as role models for young women, those with disabilities and without.

Keywords: access to higher education; equality; higher education; inclusive education; marginalisation; Sub-Saharan Africa; Tanzania; women with disabilities;

\section{Introduction}

I think that we experience a lot of barriers due to the African culture which undermines girls and women. Even at home, family members may say 'this one is a girl and, on top of that, she has a disability. She may have capabilities but, if we help her to go to school or college, would that mean anything? There is no reason to help her. It is better to leave

\footnotetext{
* Corresponding Author. Email: Margaret.tuomi@jyu.fi
} 


\section{M. Tuomi et al.}

her at home. (From the interview of Jeni, one of the Tanzanian university women with disabilities)

The recent World Bank (2009) report stresses the role of tertiary education in Sub-Saharan Africa for enhancing the capabilities and human capital for sustainable socioeconomic development. It also identifies a strong link between investment in higher education and successful poverty reduction. In Sub-Saharan Africa enrollment rates in higher education are the lowest in the world and wide gender differences remain (Bloom, Canning, \& Chan., 2006). These disparities are not only seen in the enrolment of students but also in the number of women in academic leadership (Odhiambo, 2011). Of Sub-Saharan countries, Tanzania has the lowest gross tertiary enrolment rate of just one per cent which, according to Bloom et al., correlates with its weak overall economic status. Since 2005, the enhancement of higher education has been a priority in the education development plans of Tanzania with a focus on gender balance and the quality of education (Morley, Leach, Lugg, 2009; United Republic of Tanzania, 2011; United Republic of Tanzania, 2010).

Across Sub-Saharan Africa there are approximately only 62 female students for every 100 male students in higher education (UNESCO Institute for Statistics, 2010). This underrepresentation of women that reflects social inequalities and culturally defined roles has long-term implications on the development of human capital (Morley et al., 2009). A recent survey by Negash, Olusola, \& Colucci (2010) of 32 African higher education institutions in 16 countries reported challenges in both increasing and widening participation. They highlighted that among underrepresented groups, including women and persons with disabilities, there was limited access to higher education, a low rate of participation and a high risk of dropout. The institutional factors that were associated with underrepresentation included lack of: (1) financial 
support, (2) effective support services, (3) appropriate facilities for students with disabilities, and (4) a sufficient infrastructure (ibid.). Negash et al. refer to the 1948 Declaration of Human Rights, which proclaims that higher education should be "equally accessible to all on the basis of merit” (United Nations, 1948). In addition to the 1948 Declaration, the 2006 United Nations Convention on the Rights of Persons with Disabilities (UNCRPD; United Nations, 2006) could not have been more explicit. Article 24 specifically focuses on the rights of persons with disabilities to inclusive education at all levels, including lifelong learning, without discrimination, on the basis of opportunity. In addition, Article 6 of the UNCRPD specifies the importance of guarding the human rights and fundamental freedoms of those with the multiple discriminations of being both female and having disabilities. These documents further emphasise the role of institutions of higher education in the development of equality and equity.

Globally, persons with disabilities are underrepresented in higher education. There is also a lack of reliable, comparable data on the access and participation of students with disabilities in higher education. This underrepresentation stems partly from the prevailing inequity at the primary and secondary levels of education or, in other terms, the weakness of the education system to respond to the educational potential of students with disabilities (Ebersold, 2008). While there has been significant improvement in access to education in general, the education of persons with disabilities has remained neglected. According to the World Report on Disability (World Health Organisation [WHO] and World Bank, 2011) which uses the World Health Survey data for comparison, respondents with disabilities have significantly lower rates of primary school completion and fewer mean years of education than respondents without disability. Poor rates of degree completion prevail across all age groups in both high-income and low-income countries. The primary school completion rates are significantly higher for non- 


\section{$4 \quad$ M. Tuomi et al.}

disabled children (55.6\%) than for children with disabilities (45.6\%) and very low for girls with disabilities (32.9\%) compared to the completion rate for boys with disabilities (42\%). The World Report on Disability points out that, in developing countries, more evidence on actual social and academic outcomes is needed (WHO and World Bank).

The correlation between low educational outcomes and disability is evident in the metaanalysis of 14 nationally representative surveys of 13 developing countries carried out from 1997 to 2005 regarding disability, poverty and schooling (Filmer, 2008). It was found that, in terms of the "school participation deficit”, disability, rather than any other factor, was "typically larger than deficits associated with characteristics such as gender, rural residence and economic status” (p. 159). According to Filmer, the "school participation deficit" related to disability widened from grade to grade also in those countries that had achieved relatively high enrolment rates of children without disabilities. The implications of the increasing "school participation deficit" on the development of human capital are long-term. Children with disabilities will reach adulthood denied the tools for self-sufficiency and the opportunity to make their unique contribution to society. Keeping children and young people with disabilities in school is well worth the efforts involved.

In their recent policy statement on equitable access, success and quality in higher education, the International Association of Universities (2008) emphasises that, for quality higher education, the inclusion of underrepresented groups, such as persons with [dis]abilities, is necessary. The capacity of tertiary institutions to provide equal access and adapt their resources to the needs of students with disabilities may reflect their overall openness to change and responsiveness to societal demands (Ebersold, 2008). Institutions of higher education may also be upholding traditional ideologies concerning disability and may fail to recognise the agency 
and capability of students with disabilities (Beauchamp-Pryor, 2012; Brandt, 2011). This failure can be interpreted as a lack of institutional capacity and social inclusion (Ebersold, 2008). Recent research by Richardson (2009), using academic attainment as a gauge of success in higher education, found that disablement accounted for only an insignificant $0.02 \%$ of the variation (p.134). Gidley, Hampson, Wheeler, \& Bereded-Samuel (2010) suggest that, according to an integrated approach, the application of social inclusion theory for quality higher education which realises students' academic potentials requires equitable access, engaged participation and empowered success.

In their comparative study on equality and equity in higher education in Ghana and Tanzania, Morley and Croft (2011) found that in both countries, disability was associated with great constraints, misrecognition, frustration, exclusion and, sometimes, even danger. However, students with disabilities in higher education reported the transformation of their identities as a result of their agency, advocacy and achievement. Another study by Mwaipopo, Lihamba and Njewele (2011) examined how Tanzanian policies, such as the 2005 National Strategy for Growth and Reduction of Poverty (known as MKUKUTA) and the 2004 National Policy on Disability, succeeded to improve the educational opportunities and situations of persons with disabilities. Their conclusion was that the government showed the political will to ensure equal access to higher education but failed in the assessment of achievements in practice. The studies by Morley and Croft (2011) and Mwaipopo et al. (2011) point out the significance of higher education as an opportunity for identity transformation.

The All-African Students’ Union calls for strengthening the voice of students in the higher education development and policy dialogue (Ogunlana, 2010). The African Network on Evidence-to-Action on Disability (AfriNEAD) goes beyond this by inviting contributions from 


\section{$6 \quad$ M. Tuomi et al.}

African researchers for "the dissemination of success stories about disabled students; and more stories about the personal experiences of disabled students in higher education” (Chataika, McKenzie, Swart, \& Lyner-Cleophas, 2012, p. 395). This research responds to both calls with success stories told by women with disabilities on access and participation in higher education in Tanzania.

This research investigates six women with disabilities who beat the odds and study at the University of Dar es Salaam, the first and oldest university established in Tanzania. The questions addressed are: (1) what enabled the women with disabilities to apply and gain access to higher education, (2) what facilitated their participation in higher education, and (3) what do they view as the key factors for their success?

Their perceptions on how they succeeded with their educational and academic careers offer insight into the openness to change and responsiveness of higher education not only in Tanzania, but in Sub-Saharan Africa and globally. This research also provides the women's critical views on what equality in higher education means in practice and how education brings about societal changes.

\section{Method}

Information on enrolment and demographic data concerning students with disabilities was obtained via the Dar es Salaam University Resource Centre. Women with disabilities were invited to participate in the research. All were eager to be interviewed and gave their informed consent for participation in the research. The data were collected through semi-structured interviews of six women with disabilities as a pilot of wider qualitative research on the experiences of university women with disabilities. The interviews were carried out on the university campus in 2009-2010 in Kiswahili, the language of social communication and the 
official language of the United Republic of Tanzania. The recorded interviews were transcribed and translated into English. The two researchers who speak Kiswahili verified the translations and meaning of the texts. The interview questions were based on eight themes: (1) the background and family characteristics of the women, (2) the experiences of the women before enrolling in the university, (3) their perceptions of their own disabilities, (4) the socio-cultural and economic support available to them, (5) accessibility to information concerning university studies, (6) the educational level of their parents and its impact, (7) the women's perceptions of the importance of education in their lives as women with disabilities, and (8) their visions of how they see their futures. The qualitative data were organized and analysed according to the eight themes and sub-themes which emerged from the interview material. The thematic content analysis approach (Rubin, \& Rubin, 2012; Seidman, 2013) was applied in the data analysis. Cross-referencing with tables and illustrations was used in the analysis of the responses to identify links between the themes and sub-themes. The statements of the respondents were organised following the three fundamental elements for realisation of academic potential, i.e., access, participation and success as by Gidley et al. (2010). In addition, to assist in contextualising the data, the classrooms, dormitory facilities and the university library were observed for an overview of the infrastructure and services available to the women.

The background information provided by the six women, seen in Table 1, shows their year and level of study, their self-chosen pseudonyms, age, degree programme, disability, selfperceived aetiology of their disability and other demographic details. Their disabilities included visual, auditory and physical impairments. The women study for Bachelor degrees in Fine Arts, Aquatic Sciences and Environmental Conservation, Psychology, Education, Biology, Geography and Education, and one at the Master's level in Educational Sciences. The only student with 


\section{M. Tuomi et al.}

work experience, the master's level student, was working as a teacher at the time of the interviews.

\section{[t] Insert Table 1 near here/[t]}

The respondents are listed in Table 1 according to the number of academic years they had completed in higher education at the time of the interview. Only one, Morin, described her disability with a medical diagnosis of polio. Beatrice grew up with the common belief that a curse had caused her hearing impairment. Upon enrolment, another student explained that it had not been caused by a curse, and she should move on and focus on her studies. Half of the respondents had been taken to a traditional healer to be cured of their disabilities. Amina offered the cause of her impairment as "witchcraft". She reported that a traditional healer was called in by her parents due to their concern about her eyesight. According to Amina, the healer wiped dirt on her eyes in order to cure them. The result, instead, caused her total blindness.

It is exceptional among this group of respondents that the majority of the six women come from rural areas when, in fact, a higher percentage of urban women are found in higher education (Morley et al., 2009; UNESCO Institute for Statistics, 2010). Suzy informed that, "Without schooling ... I would live in the village, be cheated, maybe get pregnant, and then be left without support.” Amina recalls missing classes when she contracted polio, the cause of her physical impairment, "I stayed in the village without going to school ... I wanted to learn so I borrowed my brother's notebooks to read on my own to reach the level of others.”

Only two of the six respondents were married, contrary to the norm of their age group. This may be seen as the reflection of the taboos connected with disabilities in Tanzanian society 
(Macha, 2002). Suzy, one of the married women, informed “... when we got married, people asked my husband, why he married a blind woman. ... how can she cook, do the laundry ... and clean his house?” Regardless of being single or married, according to Jeni, “you encounter a lot of prejudice. The African culture undermines girls and women, and even your family members say 'this one is a woman and, moreover, one with a disability'.”

\section{Findings}

As suggested by Gidley and her colleagues (2010), the process of reaching academic potential first requires students' access to higher education, then full participation in the learning process and, finally, success in their studies. For this reason the women's responses to the eight interview themes are presented here according to these three categories: access, participation and success.

\section{Access}

The first barrier to participation and success in higher education is admission to the university. Throughout their educational careers, the women told that poverty made it easy to feel defeated and to give up. In addition to determination, three areas of focus were found which enhanced the access of the women to higher education: (1) an encouraging family environment, (2) motivation from primary and secondary school teachers, and (3) sufficient financial support.

As opposed to the Tanzanian society in general, all the respondents noted that their family environment had encouraging, positive attitudes towards education. By getting an education, especially higher education, they gained value and respect within the family and were allowed to take part more fully in family discussions and decision-making. They had more autonomy and freedom to state their opinions without fear. The women reported that at the beginning of their studies it was quite challenging to manage their own affairs at the university where there was no 
one to help them with budget management and daily needs such as dressing, washing clothes, acquiring food and cooking. The help and advice from their parents, siblings and relatives were significant in this transition. Their motivation to succeed was also enhanced by technical equipment bought by the parents for the women to use in their studies.

The women reported that their primary and secondary school teachers had offered more support than their university lecturers. Due to lack of encouragement from their teachers, many girls and women with disabilities drop out from school and remain at home without an education. One woman with visual impairment stated that she was able to move forward with her academic career only after hearing about others with disabilities that had succeeded (Jeni). She realised only then that she could succeed as well.

Financial support was necessary at all levels of education. The women believed that in the absence of funding they would have had to discontinue school. All the respondents reported that their school fees were paid either by their parents, via financial assistance or with a loan. One reported that, no matter how good her grades were, without financial support, she would have been left without an education. Two women described situations where they had failed their final examinations for Forms Four and Six. Yet their parents' encouragement, motivation and willingness to pay all the extra expenses convinced them to retake their examinations and be selected for higher education.

The woman pursuing a master's degree reported that she used various sources of support. In primary education she received assistance from the district education office and, from primary to the diploma level, she had been provided with a scholarship from Canada. For her Bachelor's degree she managed to get a loan for her full tuition from the higher education loan board, and at the master's level she received a scholarship from the Belgian Development Agency (BTC). The 
women agreed that this support was essential and reduced the burden on their parents who were poor.

When the key factors of access were in place, the six were well on the road to participate in their studies. Those factors for access were: (1) an encouraging family environment, (2) teachers at the primary and secondary school levels who motivated them to continue their studies, and (3) sufficient financial support.

\section{Participation}

Once accepted to the university, full participation in university life was essential for the women with disabilities to succeed. This was achieved through: (1) their inclusion peer networks, especially in the form of peer study groups; (2) the ability of the women to circumvent obstacles in the campus infrastructure; and (3) the appropriate support of trained teaching staff. Each of the six women developed a unique strategy for success in their studies.

Peer networking and study groups enabled the university women with disabilities to live and study with non-disabled students and were significant for the women's success. The influence of peer-networking spanned over many arenas of university life such as academic studies, free-time activities and involvement in university politics. The group members encouraged and motivated each other, leading to a sense of being capable and accepted. The impact of peers at the university was especially critical for their academic achievement. Interaction with peers centred on study group discussions, finding library references, note taking, assistance in reading, and guidance from classroom to classroom. According to Vaileth: “The biggest help was my friends. I am grateful to those who helped me a lot. They gave me their notebooks to read and they never treated me badly.” Assistance from other students was necessary due to the inaccessibility of areas on campus essential for student life, such as 


\section{M. Tuomi et al.}

classrooms, dormitories and the library. Even the women with visual impairments with granted assistant readers were required to rely on their fellow students due to the fact that the readers were not allowed to enter the classroom during class time.

All the participants reported that the support provided by the university as a whole was insufficient for their needs. The women reported that small adjustments had been made in the physical environment on campus such as the removal of some steps for wheelchair access, the construction of accessible buildings, and a parking area for the vehicles of students with disabilities. Many more adjustments need to be made due to inaccessible facilities caused by steps, hedges, fences and unsuitable toilets.

Only the women with visual impairments reported support provided by the university in the form of specialised equipment for the visually impaired, such as verbal computers, from the Tanzania Education Authority, as well as separate examination areas so that the Braille machines did not disturb others. The facilities and equipment were reported as old and functioned slowly, causing difficulties for them to meet their assignment and test deadlines. Lack of training, however, in the use of the technology made its use difficult. Also, the amount of material and equipment available was not enough for the number of students who needed to use them. This lack of proper equipment was acute among the students from low income families. The financial support provided by parents and family were pivotal for the women with disabilities to succeed socially, culturally, technologically and economically. Women coming from richer families believed that having equipment such as typewriters, Perkins, Braille papers and machines, earphones, mopeds, wheelchairs, note takers, course outlines and books helped them to study more easily. By the same token, the women from poorer families expressed that the lack of 
facilities and an unsupportive environment hindered them because they had to struggle to use the few resources offered by the university.

Teachers' encouragement and support were seen as crucial for the full participation of the women. They played a significant role in facilitating the respondents' participation by providing materials, setting up special equipment and adapting their teaching style to meet their needs. “One teacher helped me a lot”, said Vaileth, “... and I studied well, thanks to the notes and explanations that she gave me.” The extra help they received was regarded as a significant contribution to their success. Examples of the extra help offered were that some teachers enlarged the font on examinations and increased the amount of time for tests and assignments. Some teachers gave the women preferential seating which enabled the students to become known to their teachers. They facilitated opportunities and privileges in the distribution of the materials. They made it easier for the students to hear the lectures and ask questions. These accommodations were all central for them to succeed academically. The women reported that, without their teachers' support, they were at a high risk to drop out or fail to manage in their academic environment. They also mentioned the benefits of services such as guidance and counselling. Those teachers who offered encouragement, commitment and effort increased the academic strength of the women.

The essential features needed for participation according to the university women with disabilities were: (1) full inclusion in peer networks, especially in the form of study groups; (2) the encouragement and support of teachers trained to meet the needs of all their students; and (3) a campus with an accessible infrastructure, proper equipment and staff trained to use it. This was especially considered important by the women from lower income families. 


\section{M. Tuomi et al.}

\section{Success}

How then is academic success determined? Considering the odds against women with disabilities in Tanzania, success can be defined as full integration into academic life. Also, their success is found in their motivation and fortitude to face whatever challenges they meet in their academic career path. Personal ambition was identified by half of the respondents as essential in achieving a degree in higher education. The study found that being determined helped the women to create a sense of autonomy, freedom and independent life experience. Their personal motivation acted as a pushing factor to find alternatives to reach their goals. Ambition also created a sense of tolerance, discipline and motivation. They believed that uneducated women with disabilities were living a poor life because they had no goals and were not educated. They believed that higher education was the tool which could help them to overcome social and cultural barriers and advance their financial position. These beliefs reinforced them to assert their goals to reach higher education. According to Jeni, “education helps one to build self-confidence. If I have challenges, I understand that it is not due to disability, and instead of complaining, I can find ways to overcome these challenges.”

There was consensus among the respondents in certain areas: (1) all had high ambitions to complete higher education and believed that having a degree would resolve problems related to their disability, (2) all reported an encouraging family environment with positive attitudes toward education, and (3) all had received a grant to pursue a Bachelor's Degree from the higher education loan board. That is, each had an inner motivation, the encouraging support of their family and the financial possibility to realise their goals. The women stressed the need for determination and personal ambition for social and economic independence. Amina emphasised the importance of her education even further. She stated, "It has helped me to know myself as a 
disabled girl in society and my capabilities. I can do everything that other women can do, for example, to compete for a leadership position at the university or elsewhere. Now I see myself as somebody who is capable.”

Despite the discouragements they had experienced, the women spoke of their need to persevere in their studies to have a successful life. The women believed that when they finished their Bachelor Degrees their economic status would change. They expected to get good jobs and live a good life. Suzy reported, "I will have my own income! ... I could continue studies up to the Master’s degree and when I get a PhD I will be very happy.” Morin’s instructor had taught that if she would be diligent, “... the future will be interesting. If you can manage to perform well, you will have a chance for further education. It will be very easy to get a job and sponsorship for completion of a PhD because you are a woman and you are studying science.” Morin continued, "Few women in Tanzania study science. This encouraging situation helped me to increase my commitment and effort until I managed to reach university level. My plan is to be a professor.”

It was clear that all six women showed determination to complete their studies. They saw a degree in higher education as the "way out" of their difficult situation as Tanzanian women with disabilities. According to Morin, “education is very important for people with disabilities. When you have an education you can look for a job and once you have employment you can meet all your essential needs. I, for example, am no longer depending on my parents.” On the other hand, the women felt responsible for helping their own ageing parents, as is the custom in Tanzania, “they have helped me a lot, when they get older, they will depend on my support” (Suzy). One respondent offered how education would change her status, "I want to succeed, in education, life and economically” (Vaileth). 


\section{M. Tuomi et al.}

\section{Discussion}

What can we learn from these six women who, like all university students, strive for agency and autonomy? They emphasise the same requirements that apply to all students: equitable access, engaged participation and empowered success (see Gidley et al., 2010). According to the women interviewed, the key factors enabling their access to higher education were the encouragement of their families and teachers in primary and secondary schools and having sufficient financial support. The importance of support in transitions from secondary schools to higher education is also emphasised by Lihamba, Mwaipopo, \& Shule (2006) who studied the functioning of affirmative action for gender parity. They suggest outreach programmes in secondary schools to find and prepare suitable female candidates for higher education admission, and the empowerment of women during their studies by the enhancement of their skills and confidence for educational and career advancement. The research by Negash et al. (2010) on tertiary institutions in Africa concur that financial support, effective support services, facilities for students with disabilities and sufficient infrastructure are the key institutional factors to improve access, participation and retention.

In this study the six women reported that active participation in university life was facilitated by their inclusion in peer networks, especially in study groups. The importance of peers was also emphasised by Runhare (2004) in his study on students with disabilities in Zimbabwe. Moreover, networking was important in all phases of university life, not only in academic activities but also for the social, political and other aspects of their lives. According to the women, their primary and secondary school teachers offered more support than their university lecturers. They found special needs education professionals to be more supportive, collaborative, creative and innovative in their teaching and to have more advanced skills in the 
use of suitable learning materials. The women stressed the need for encouraging and supportive teachers, trained to meet the needs of their students, and, at the university level, an accessible infrastructure with proper equipment and trained staff to use it. In Zimbabwe also, students with disabilities valued the inclusive education policy for higher education but were dissatisfied with the quality of support provided by their university lecturers (Runhare). In a previous study on barriers to higher education by Tungaraza (2010), women with disabilities reported the negative attitudes of teachers, poor availability of assistive technologies and physical barriers as the main challenges in university studies. In this study, with a focus on the enabling factors, all the women interviewed had high motivation to finish their degrees and believed that attainment of their diplomas would resolve their disability-related problems. They emphasised the importance of their families’ positive attitudes towards education and having financial support in place.

All six women were concerned that those with disabilities face an increased risk of marginalisation and poverty. Beatrice stated that "without education one would be on the street begging." Morin continues that, without education, “one would have to depend on others for everything", and Amina offers "without education, if you become sick, some die due to lack of money and lack of education ... women are begging on the street because they lack an education.” In the context of Tanzania, the women's views highlight the significance of education in addressing the vicious circle of marginalisation in society and poverty, an issue relevant not only elsewhere in Sub-Saharan Africa but also globally. According to the World Bank analysis of tertiary education in Sub-Saharan Africa (2009, p. xxi), "Each additional year of education can yield 10 percent to 15 percent returns in the form of higher wages.” In the case of persons with disabilities, access and participation in higher education can significantly reduce 
their risk of poverty. The short term costs and efforts involved in, for example, building accessible classrooms are well-worth the long term advantages and societal outcomes.

The Tanzanian university women with disabilities interviewed for this research emphasised that all the actors they met along their educational path needed more understanding and knowledge regarding inclusive practices. At the lower levels, teachers and guidance counsellors can encourage women with disabilities to pursue higher education and give them, and their parents, information on higher education enrolment, support systems available and employment opportunities. This could increase their motivation to continue to higher education. For full participation in higher education to take place, the respondents viewed integration into campus life, the support of teachers, and the entire university infrastructure as key elements in their success. The university women with disabilities saw that collaboration with their families, teachers, peers and the specialists from the university resource centre for students with disabilities was crucial for their educational success. Peer networks, especially study groups, found to be so crucial, need to be in place.

For women with disabilities to have access to higher education and full participation in university life, information must be disseminated to the society at large, especially to the academic community. Teachers and guidance counsellors at the lower educational levels should provide information, encouragement and inspiration for girls with disabilities to attend higher education, through visits or mentoring from alumnae with disabilities. Girls with disabilities who are capable and interested in higher education should be found and guided along the pathway of lifelong learning. The women all spoke of the importance of girls with disability to have educated role models, and they were eager to be those models in the future. According to Amina, "We women with disabilities who have studied are needed to motivate those in school to warn 
them about the risks in the world and encourage them to study because, without education, we women with disabilities cannot succeed.” Additionally, Amina spoke of encouraging girls to avoid listening to men who try to distract them from their studies, abuse them and leave them with nothing. Parents should strive to construct supportive environments and to instil selfdetermination and agency for their daughters to meet their goals.

Inclusive higher education, as Chataika and her colleagues (2012) remind us, is not only about accessibility and participation for students with disabilities, but about educating all students. Orientations at the beginning of the academic year could recognise the fact that students with disabilities are an integral part of university life and the student body. Training and orientation programmes for university staff must include practical information enabling collaboration and learning for all students, including those with disabilities. According to Ebersold (2008), accommodation to the needs of students with disabilities is a quality improvement issue in higher education. While little can be generalised based on the experiences of six women, their comments shed light on what is needed to achieve the goals set by the United Nations in 1948 and again in 2006 for equal access to higher education based on merit and potential. There is still a lot of work to be done and access, participation and success in higher education are steps towards the realisation of these human rights.

More research is needed on the views of university women with disabilities, those precious few who have managed, beyond all odds, to gain admission to higher education and make their unique mark on the future. They give us more knowledge to achieve the goals set in the Declaration of Human Rights and UNCRPD, and show encouraging prospects for the future both locally and globally. Their presence in higher education can help start the long process of tearing down long-held fallacies and taboos surrounding disability in society at large. What each of these 
women has to offer will impact society in their own individual way. As they complete their studies and move out into the society, they not only help themselves but become role models who encourage other women, those with disabilities and without that they too can succeed. Suzy currently visits schools to tell the girls that, "Your sister (referring to herself) is blind but she has gone to the university!” She continues, "I like to be a role model. I cannot see but I have reached a higher level of education than many of those who can!”

\section{Acknowledgement}

There was no research funding for this study, and no restrictions have been imposed on free access to, or publication of, the research data.

\section{References}

Beauchamp-Pryor, K. (2012). From absent to active voices: Securing disability equality within higher education. International Journal of Inclusive Education, 16(3), 283-295. doi: $10.1080 / 13603116.2010 .489120$

Bloom, D., Canning, D., \& Chan, K. (2006). Higher education and economic development in Africa. Washington, DC: World Bank, Human Development Section. Retrieved from http://ent.arp.harvard.edu/AfricaHigherEducation/Reports/BloomAndCanning.pdf

Brandt, S. (2011). From policy to practice in higher education: The experiences of disabled students in Norway. International Journal of Disability, Development and Education, 58, 107 -120. doi: 10.1080/1034912X.2011.570494

Chataika, T., McKenzie, J. A., Swart, E., \& Lyner-Cleophas, M. (2012). Access to education in Africa: Responding to the United Nations Convention on the Rights of Persons with Disabilities. Disability \& Society, 27, 385-398. 
Ebersold, S. (2008). Adapting higher education to the needs of disabled student: Development, challenges and prospects. In Higher Education to 2030, Vol. 1, Demography, 221-239. Paris: OECD.

Filmer, D. (2008). Disability, poverty, and schooling in developing countries: Results from 14 household surveys. The World Bank Economic Review, 22, 141-163. doi:10.1093/wber/lhm021

Gidley, J. M., Hampson, G. P., Wheeler, L., \& Bereded-Samuel, E. (2010). From access to success: An integrated approach to quality higher education informed by social inclusion theory and practice. Higher Education Policy, 23, 123-147.

International Association of Universities. (2008). Equitable access, success and quality in higher education: A policy statement by the International Association of Universities. Utrecht, The Netherlands: International Association of Universities.

Lihamba, A., Mwaipopo, R., \& Shule, L. (2006). The challenges of affirmative action in Tanzanian higher education institutions: A case study of the University of Dar es Salaam, Tanzania. Women's Studies International Forum, 29, 581-591.

Macha, E. (2002). Gender, disabilities and access to education in Tanzania (Doctoral dissertation). Retrieved from http://etheses.whiterose.ac.uk/282/1/uk bl_ethos_270754.pdf.

Morley, L., \& Croft, A. (2011). Agency and advocacy: Disabled students in higher education in Ghana and Tanzania. Special Issue on African Higher Education: Researching Absences, Equalities and Aspirations. Research in Comparative and International Education, 6(4), 383-389. 
Morley, L., Leach, F., \& Lugg, R. (2009). Democratising higher education in Ghana and Tanzania: Opportunity structures and social inequalities. International Journal of Educational Development, 29, 56-64.

Mwaipopo, R. N., Lihamba, A., \& Njewele, D. C. (2011). Equity and equality in access to higher education: The experiences of students with disabilities in Tanzania. Special Issue on African Higher Education: Researching Absences, Equalities and Aspirations, Research in Comparative and International Education, 6, 415-429.

Negash, Z., Olusola, O., \& Colucci, E. (2010). Access, participation and retention in Africa: Evidence from a survey on tertiary institutions. Evidence from a Survey on Tertiary Institutions. Workshop, Addis Ababa, Ethiopia.

Odhiambo, G. (2011). Women and higher education leadership in Kenya: A critical analysis. Journal of Higher Education Policy and Management, 33, 667-678.

Ogunlana, O. (2010). African student perspectives on access and retention: The AASU perspective on access, diversity and retention challenges in Africa. In Access to success: Fostering trust and exchange between Europe and Africa: Project compendium (pp. 108113). Brussels, Belgium: European University Association. Retrieved from http://www.accesstosuccessafrica.eu/web/images/literature/access\%20to\%20success\%20project\%20compendium.pdf

Richardson, J. T. E. (2009). The academic attainment of students with disabilities in UK higher education. Studies in Higher Education, 34(2), 123-137.

Rubin, H. J., \& Rubin, I. S. (2012). Qualitative interviewing: The art of hearing data (3rd ed.). Thousand Oaks, CA: Sage. 
Runhare, T. (2004). Provision of equal education for students with disabilities at tertiary institutions in Zimbabwe: Prospects and barriers. Journal of Social Development in Africa, 19, 151-167.

Seidman, I. (2013). Interviewing as qualitative research: A guide for researchers in education \& social sciences (4th ed.). New York: Teachers College, Columbia University.

Tungaraza, F. D. (2010). Accomplishments and challenges facing students with disabilities at the University of Dar es Salaam: Thirty years of navigating The Hill'. Education and Development: Journal of the Faculty of Education, University of Dar es Salaam, 29, 134155.

United Nations. (1948). Universal Declaration of Human Rights. United Nations General Assembly resolution 217 (III) of 10 December 1948.

United Nations. (2006). Convention on the rights of persons with disabilities. New York: Author.

United Nations Educational, Scientific and Cultural Organization (UNESCO) Institute for Statistics. (2010). Global Education Digest 2010: Comparing education statistics across the world: Special focus on gender. Quebec, Canada: Author. Retrieved from http://www.uis.unesco.org/Library/Documents/GED_2010_EN.pdf

United Republic of Tanzania. (2009). Basic Education Statistics in Tanzania 2005-2009. Dar es Salaam: Ministry of Education and Vocational Training. Retrieved from http://educationstatistics.moe.go.tz/moe/\#

United Republic of Tanzania. (2010). Education Sector Development Programme: Secondary Education Development Programme II (July 2010-June 2015. Final Draft, June 2010. Dar es Salaam: Ministry of Education and Vocational Training. 
24 M. Tuomi et al.

United Republic of Tanzania. (2011). Basic Education Statistics in Tanzania 2007-2011. Dar es Salaam: Ministry of Education and Vocational Training. Retrieved from http://educationstatistics.moe.go.tz/moe/\#

World Bank. (2009). Accelerating catch-up: Tertiary education for growth in sub-saharan Africa. Washington, DC: Author. Retrieved from http://siteresources.worldbank.org/INTAFRREGTOPEDUCATION/Resources/ebook_ACU.pdf

World Health Organization and the World Bank. (2011). World Report on Disability. Retrieved from http://whqlibdoc.who.int/publications/2011/9789240685215_eng.pdf. 